\title{
Developing a Real-Time PCR Assay for Direct Identification and Quantification of Pratylenchus penetrans in Soil
}

Richard Baidoo, Guiping Yan, and Seenivasan Nagachandrabose, North Dakota State University, Department of Plant Pathology, Fargo, 58108; and Andrea M. Skantar, USDA-ARS, Mycology and Nematology Genetic Diversity and Biology Laboratory, Beltsville, MD 20705

\begin{abstract}
The root-lesion nematode Pratylenchus penetrans is a major pathogen of potato worldwide. Yield losses may be exacerbated by interaction with the fungus Verticillium dahliae in the potato early dying disease complex. Accurate identification and quantification of $P$. penetrans prior to planting are essential for developing effective integrated pest control measures. However, distinction between $P$. penetrans and other Pratylenchus spp. based on morphology is a tedious task. A SYBR Green I-based qPCR assay was developed to discriminate, identify, and quantify $P$. penetrans in field soil. $P$. penetrans-specific qPCR primers were designed from the D2-D3 region of the 28S rDNA. The specificity of the assay was evaluated using eight isolates of $P$. penetrans populations and 31 isolates of other nematode species. A standard

curve relating threshold cycle and log values of nematode number was generated from artificially infested soils. There was a high correlation between the $P$. penetrans numbers artificially added to soil or estimated from naturally infested field soils by conventional methods, and the numbers quantified using the qPCR assay. Grinding the field soil prior to DNA extraction improved $P$. penetrans detection from soil. The qPCR assay will not only be useful for differentiating $P$. penetrans from mixed populations of Pratylenchus spp., but also for efficient detection and quantification of $P$. penetrans from field soil. The assay requires no expertise in nematode taxonomy and morphology, and may serve as a useful diagnostic tool in research, diagnostic labs, and extension services for pest management.
\end{abstract}

The root-lesion nematode, Pratylenchus penetrans is one of the most economically damaging species within the genus Pratylenchus. It has a worldwide distribution but is commonly found in temperate regions on a variety of crops. In Europe, $P$. penetrans is known to be damaging on field crops, vegetables, and ornamental plants (Coolen and D'Herde 1970; Pudasaini et al. 2007; Talavera et al. 2001; Westerdahl et al. 2003). The nematode is also recorded on different crops in Japan, Canada, Algeria and Morocco (Mokrini et al. 2012; Olthof and Potter 1973; Sato et al. 2007, 2010; Troccoli et al. 1992). In the U.S.A., the nematode is a major threat to many crops, especially potato growing in the northeastern part of the country (Francl et al. 1987; MacGuidwin and Rouse 1990; Martin et al. 1982; Rowe et al. 1987; Thies et al. 1995; Yan and Plaisance 2016). The nematode infects potato tubers and causes a scabby appearance with sunken lesions or dark, wart-like bumps that turn purple on tubers in storage. Yield losses may be exacerbated by interaction with the fungus Verticillium dahliae Kleb, causing a disease known as potato early dying disease complex (PED) (MacGuidwin and Rouse 1990; Martin et al. 1982; Rowe et al. 1987). This disease can lead to premature vine death and significant reduction in tuber size and total marketable yield and therefore can become a limiting factor in potato production. Reported yield reductions range from very slight to 30 to 50\% (MacGuidwin and Rouse 1990; Martin et al. 1982; Rowe et al. 1985, 1987).

Seinhorst (1998) established that a significant correlation exists between the preplanting population numbers and the amount of damage caused by plant-parasitic nematodes. This makes accurate identification and quantification of $P$. penetrans prior to planting essential for developing effective integrated pest control measures and making yield-loss risk assessment. However, other Pratylenchus species, namely $P$. crenatus, $P$. neglectus, $P$. scribneri, and $P$. thor$n e i$, are commonly found coexisting with $P$. penetrans on potato in

Corresponding author: Guiping Yan, E-mail: guiping.yan@ndsu.edu

*The $\boldsymbol{e}$-Xtra logo stands for "electronic extra" and indicates that three supplementary figures are available online.

Accepted for publication 2 May 2017.

() 2017 The American Phytopathological Society
North America (Brown et al. 1980; Kimpinski 1979; Wheeler et al. 1992). This coexistence makes it more challenging to reliably identify and quantify $P$. penetrans using the traditional microscopic enumeration methods based on morphological characters owing to the presence of only a small number of diagnostically valid characters between the Pratylenchus species (Luc 1987; Waeyenberge et al. 2009). Moreover, intraspecific variability has been demonstrated in P. penetrans (Tarte and Mai 1976). Molecular technologies provide a rapid and accurate alternative to the microscopic identification and quantification methods.

Quantitative PCR (qPCR) strategies using species-specific primers have been developed for plant-parasitic nematodes (Berry et al. 2008; Madani et al. 2005; Mokrini et al. 2012; Wishart et al. 2002; Ye 2012; Zijlstra et al. 2000). However, these methods require that the nematode is extracted from the soil prior to DNA extraction and amplification, which increases identification and/or quantification time, cost, and labor. Molecular assays for identification and quantification of specific plant-parasitic nematodes directly from soil DNA extracts have recently been developed (Goto et al. 2009; Li et al. 2014; Sato et al. 2010; Yan et al. 2008, 2012, 2013b). However, only few research describing methods for identification and quantification of $P$. penetrans have been reported (Koyama et al. 2016; Mokrini et al. 2013; Sato et al. 2007, 2010, 2011). However, the soil compactor used in the majority of these studies was a specialized machinery tailored to this end and is not readily available. A sensitive, rapid, specific, and reliable molecular diagnostic method is needed to identify and quantify $P$. penetrans directly in DNA extracts from soil for successful management. The goal of this study was therefore to develop a molecular assay to discriminate and quantify $P$. penetrans in commercial potato fields in Minnesota. The specific objectives were to i) develop a species-specific qPCR assay to identify $P$. penetrans and to discriminate the species from other closely related Pratylenchus species, namely $P$. crenatus, $P$. neglectus, $P$. scribneri, and $P$. thornei and other nematodes commonly found in $\mathrm{MN}$ potato fields; ii) develop a method to improve $P$. penetrans detection efficiency in field soils; and iii) develop a qPCR assay to detect and quantify $P$. penetrans directly from field soil DNA extracts.

\section{Materials and Methods}

DNA extraction from pure culture and soil. Separate cultures of Pratylenchus spp., namely $P$. penetrans, $P$. neglectus, $P$. thornei, and $P$. scribneri were maintained on carrot discs at $22^{\circ} \mathrm{C}$ in an incubator 
for 3 months (Pinochet et al. 1995) at the North Dakota State University Nematology Laboratory. The nematodes were extracted from the carrot discs for DNA extraction. A single nematode of each species was transferred separately into $10 \mu l$ of distilled water on a concave glass slide and crushed with a dental pick. The suspension $(10 \mu \mathrm{l})$ containing nematode pieces was pipetted into a $0.5 \mathrm{ml}$ sterile Eppendorf tube containing $10 \mu \mathrm{l}$ of extraction buffer $(2 \mu \mathrm{l}$ of $10 \times$ PCR buffer, $2 \mu \mathrm{l}$ of Proteinase $\mathrm{K}$ [600 $\mu \mathrm{g} / \mathrm{ml}$ ], and $6 \mu \mathrm{l}$ of sterile water) and the tubes were incubated at $-20^{\circ} \mathrm{C}$ for $20 \mathrm{~min}$ followed by $1 \mathrm{~h}$ incubation at $65^{\circ} \mathrm{C}$ and then $10 \mathrm{~min}$ incubation at $95^{\circ} \mathrm{C}$ (Subbotin et al. 2001). The DNA suspension was stored at $-20^{\circ} \mathrm{C}$ and used as DNA template. The same procedure was followed to extract DNA from other vermiform nematode species commonly found in potato fields in Minnesota and North Dakota.

Total DNA was extracted from artificially infested soils and naturally infested field soils using the MoBio PowerSoil DNA Isolation Kit (MOBIO Laboratories Inc, Carlsbad, CA) according to the manufacturers' protocol and the MOBIO Vortex Adapter tube holder according to the manufacturer's recommendations. DNA extract from soil was stored at $-20^{\circ} \mathrm{C}$ prior to qPCR.

Primer design, specificity, and sensitivity. The D2-D3 expansion region of the 28S rRNA gene of three populations of $P$. penetrans (PT-Edling_1, PT-DeChene_1, and PT-DeChene_2) originating from three different potato fields in $\mathrm{MN}$ was sequenced using the D2A/D3B universal primer set (Subbotin et al. 2008) (Supplementary Fig. S1) and deposited in GenBank with the following accession numbers: PT-Edling_1 = KY969631, PT-DeChene_1 = KY969632, PT-DeChene_2 = KY969633. The sequence information was compared with the published D2-D3 sequence information of $P$. penetrans and other Pratylenchus spp. in GenBank (BLAST option, http://www.ncbi.nlm.nih.gov/). All the D2-D3 sequences collected (Table 1) were aligned using the MegAlign Pro package within the DNASTAR software (Madison, WI) (Supplementary Fig. S2). To determine putative species-specific DNA fragments for $P$. penetrans, regions of the D2-D3 sequences conserved within $P$. penetrans but divergent from other Pratylenchus spp. for the aligned sequences were selected using the SeqBuilder module software package in DNA STAR. Preliminary evaluation of the primers was based on annealing temperature, GC content, and potential for self-duplex or primer dimer formation. The potential speciesspecific primers were further screened by looking for their presence in sequences stored in GenBank via BLAST. Putative primers were synthesized and salt-purified by Eurofins MWG Operon LLC (Huntsville, AL). Each primer pair was evaluated again on the basis of target specificity, amplification efficiency, endpoint fluorescence, and melting curve profile. Eventually, the forward primer DechenePp-F (5'-GGTTTTCGGGCTCATATGGGTTC-3') and the reverse primer Dechene-Pp-R (5'-TTTACGCCGAGAGTGGGATTGTG$3^{\prime}$ ) producing a 111 bp product (Supplementary Fig. S3) was chosen and used for all the experiments. This primer pair was evaluated for specificity to $P$. penetrans using DNA from eight isolates of $P$. penetrans from the U.S.A. and 12 isolates of other Pratylenchus spp., and 19 isolates of other plant-parasitic nematodes (Table 2). Nematode DNA extract from soil containing a nematode community including Helicotylenchus sp., Hoplolaimus sp., Tylenchorhynchus sp., Heterodera sp., and Paratrichodorus sp. commonly found on potato fields was used as a control, together with a soil DNA extract from potato field soil without detectable $P$. penetrans.

Detection sensitivity of the assay was performed using a fine textured sandy-loam soil, one of the field soil samples that did not have any detectable $P$. penetrans from De Chene. The soil, while moist, was autoclaved $\left(121^{\circ} \mathrm{C}, 115 \mathrm{kPa}\right)$ for $30 \mathrm{~min}$ for two consecutive days before use. Different numbers of $P$. penetrans $(0.5,1,2,3$, and 5) were added to $0.5 \mathrm{~g}$ of autoclaved soil followed by soil DNA extraction and qPCR amplification for each level of infestation in triplicates. The sensitivity of the qPCR assay was determined by detection of quantification cycle $(\mathrm{Cq})$ values at the minimum level of infestation.

Real-time PCR assay. The qPCR assay was performed using the Bio-Rad CFX96 Touch Real-time PCR Detection System (Bio-Rad
Laboratories, Inc., Hercules, CA, U.S.A.). The SsoAdvanced Universal SYBR Green Supermix (Bio-Rad) was used with $1.0 \mu \mathrm{l}$ DNA template and $0.5 \mu \mathrm{M}$ primer concentration, according to the instructions. The cycling conditions were as follows: incubation at $95^{\circ} \mathrm{C}$ for $5 \mathrm{~min} ; 35$ cycles of $95^{\circ} \mathrm{C}$ for $10 \mathrm{~s}$ and $66^{\circ} \mathrm{C}$ for $20 \mathrm{~s}$; and $72^{\circ} \mathrm{C}$ for $30 \mathrm{~s}$ followed by melting curve analysis using the default settings to evaluate the amplification specificity. Nontemplate control, using $\mathrm{ddH}_{2} \mathrm{O}$ instead of DNA in the PCR, was run for each experiment. The data were analyzed using Bio-Rad CFX Manager Software V3.1. The Cq value was determined at the default settings. PCR product identity was confirmed by electrophoresis on a $2 \%$ agarose gel.

Development and validation of standard curves. The soil used for the generation of the standard curve was tested for the presence of PCR inhibitors. DNA was extracted from a total of $100 P$. penetrans (mixed juveniles and adults) maintained in a carrot culture and serially diluted $(1,1 / 3,1 / 9,1 / 27,1 / 81,1 / 243)$ with PCR grade water. A similar dilution series was generated using an extract of the autoclaved De Chene field soil. Standard curves were constructed by plotting log value of DNA against Cq number. Presence or absence of PCR inhibitors in De Chene soil was verified by comparing amplification efficiency and the $\mathrm{Cq}$ values from serial dilutions of DNA in the soil extract to that from dilutions in water (Yan et al. 2012, 2013b)

The standard curve for the qPCR assay was then generated from a specified number of $P$. penetrans added to a sterilized De Chene soil. Quarter-gram samples of the soil were infested with vermiform $P$. penetrans from pure culture at five population densities $(0.5,1$, $5,25,125$, and 625 per $0.25 \mathrm{~g}$ of soil). Each infestation level and DNA extraction was done in triplicate and the qPCR amplification in duplicate. The soil standard curve was generated by plotting $\mathrm{Cq}$ versus $\log$ of the number of $P$. penetrans per gram of soil. Amplification efficiencies and the slopes of the plots were automatically

Table 1. Pratylenchus spp. and GenBank accession numbers of the 28S rRNA (D2/D3) sequences used in this study for designing $P$. penetrans specific primers

\begin{tabular}{lcc}
\hline Species/isolate & Accession number & Origin \\
\hline PT-Edling_1 & KY969631 & U.S.A. \\
PT-De Chene_1 & KY969632 & U.S.A. \\
PT-De Chene_2 & KY969633 & U.S.A. \\
$P$. penetrans & JX046990.1 & Netherlands \\
$P$. penetrans & JX046986.1 & Netherlands \\
$P$. penetrans & JX046970.1 & Chile \\
$P$. vulnus & JQ003992.1 & Japan \\
$P$. vulnus & JX047007.1 & U.S.A. \\
$P$. vulnus & JQ003994.1 & Japan \\
$P$. vulnus & JX261945.1 & N/A \\
$P$. vulnus & JX047010.1 & U.S.A. \\
$P$. pseudopratensis & JX261965.1 & N/A \\
$P$. coffeae & HQ688681.1 & Cambodia \\
$P$. coffeae & AF170436.1 & China \\
$P$. scribneri & JX047005.1 & China \\
$P$. scribneri & JX047002.1 & China \\
$P$. scribneri & EU130865.1 & China \\
$P$. speijeri & KF974698.1 & China \\
$P$. speijeri & KJ698686.1 & China \\
$P$. loosi & KF430796.1 & Japan \\
$P$. loosi & KF430797.1 & Japan \\
$P$. hexincisus & DQ498832.1 & N/A \\
$P$. floridensis & AF170437.1 & N/A \\
$P$. neglectus & HM469438.1 & China \\
$P$. neglectus & JX046968.1 & China \\
$P$. neglectus & JX046969.1 & China \\
$P$. thornei & JX261963.1 & N/A \\
$P$. thornei & KT213559.1 & N/A \\
$P$. thornei & EU130880.1 & U.S.A. \\
$P$. zeae & JN020930.1 & U.S.A. \\
\hline N/A ind & JN020929.1 & U.S.A. \\
\hline
\end{tabular}

${ }^{\mathrm{a}}$ N/A indicates information is not available. 
generated from the slope of a plot of cycle threshold $(\mathrm{Cq})(\mathrm{y}$-axis) and $\log$ of DNA (x-axis) $\left(\mathrm{E}=10^{(1 /-\mathrm{m})}-1\right.$; where $\mathrm{m}$ is the slope). The soil standard curve was validated using the autoclaved De Chene soil inoculated with lower numbers of vermiform $P$. penetrans at $1,5,10$, 20,40 , and 80 per $0.25 \mathrm{~g}$ of soil. DNA was extracted from the infested soil and qPCR assay was used to quantify the number of nematodes in each level of infestation.

Assessing the effect of grinding field soil on detection efficiency. De Chene field soil without detectable $P$. penetrans was autoclaved as above and inoculated with $P$. penetrans 5 or 10 nematodes per $20 \mathrm{~g}$ of soil. Each population density was either ground into a fine texture or unground prior to DNA extraction. DNA was extracted in triplicate for each infestation level using $0.25 \mathrm{~g}$ of soil. Additionally, four field soil samples naturally infested with $P$. penetrans (Y2P1 and $\mathrm{P} 25$, Y2P25, and De Chene-1) were either ground or unground and DNA was extracted in triplicate for each treatment. A qPCR was carried out for each treatment using the Dechene-Pp-F/R primers. Detection efficiency was determined by the percentage of the total number of observations detectable by the assay.

Pratylenchus penetrans detection and quantification in field soils. The qPCR assay was validated by comparing $P$. penetrans estimates determined by the qPCR assay and two conventional methods: Centrifugal sugar flotation (Jenkins 1964) and Whitehead tray method
(Whitehead and Hemming 1965). A total of 20 soil samples from potato, corn, and wheat fields naturally infested with different population densities of $P$. penetrans and other plant-parasitic and nonplant-parasitic nematodes were collected from MN. For each field soil sample, $600 \mathrm{~g}$ was collected for molecular detection and quantification and traditional extraction and quantification methods. The $600 \mathrm{~g}$ field soil was mixed thoroughly and divided into three subsamples of $200 \mathrm{~g}$ each. Two sets of subsamples were used for nematode identification and quantification using microscopy-based procedures and the third set for DNA extraction and qPCR. For the molecular assay, $200 \mathrm{~g}$ of the field soil was air-dried at room temperature in Petri dishes overnight $(9 \mathrm{~h})$ and ground in $70 \times 90 \mathrm{~mm}$ porcelain mortar with pestle (VWR, Randor, PA, U.S.A.) for 4 min to obtain a smooth, homogenous texture; stones, roots debris, and other materials were removed. A subsample of $0.25 \mathrm{~g}$ was collected by at least 30 tiny scoops from different parts of the sample using a spatula. DNA was extracted from the $0.25 \mathrm{~g}$ subsample using the MoBio PowerSoil DNA Isolation Kit and amplified using the $P$. penetrans species-specific primer set Dechene-Pp-F/R. DNA extractions and qPCR amplifications were performed three times for each field sample under the optimum conditions as described above. A no-DNA template (water) was used as a negative control and DNA from pure $P$. penetrans suspension was used as a positive control.

Table 2. Plant-parasitic nematodes used to evaluate specificity of Pratylenchus penetrans primers used in this study for the qPCR assay

\begin{tabular}{|c|c|c|c|c|c|c|}
\hline Code & Species & $\mathbf{C q}$ & Host & Origin & Source & Reference \\
\hline P.P 9C1 & P. penetrans & 27.23 & Potato & MN, U.S.A. & G. Yan & Author's collection \\
\hline P.P 154 & $P$. penetrans & 23.42 & Potato & MN, U.S.A. & G. Yan & Author's collection \\
\hline P16 & P. penetrans & 23.92 & Potato & MN, U.S.A. & G. Yan & Author's collection \\
\hline P.P. Edling & P. penetrans & 25.39 & Potato & MN, U.S.A. & G. Yan & Author's collection \\
\hline De Chene-1 & P. penetrans & 24.15 & Potato & MN, U.S.A. & G. Yan & Author's collection \\
\hline P. P67 & $P$. penetrans & 24.00 & Potato & MN, U.S.A. & G. Yan & Author's collection \\
\hline P-59 & P. penetrans & 23.45 & Potato & MN, U.S.A. & G. Yan & Author's collection \\
\hline Pp-W & P. penetrans & 23.55 & Potato & WI, U.S.A. & A. Skantar & Yan et al. (2013a) \\
\hline Pc & P. crenatus & $\mathrm{N} / \mathrm{A}^{\mathrm{a}}$ & Grass & MD, U.S.A. & A. Skantar & Yan et al. (2013a) \\
\hline P.t Oregon & P. thornei & N/A & Wheat & OR, U.S.A. & R. Smiley & Yan et al. (2013a, b) \\
\hline $\mathrm{Pt}$ & P. thornei & N/A & Wheat & U.S.A. & R. Smiley & Yan et al. (2013a, b) \\
\hline $\mathrm{Pn}-\mathrm{O}$ & P. neglectus & N/A & Wheat & OR, U.S.A. & R. Smiley & Yan et al. (2013a) \\
\hline Pn-N & P. neglectus & N/A & Wheat & ND, U.S.A. & G. Yan & Yan and Plaisance (2016) \\
\hline Pz21 & P. zeae & N/A & Spider lily & Singapore & A. Skantar & Yan et al. (2016b) \\
\hline Pz20 & P. zeae & N/A & Corn & NC, U.S.A. & A. Skantar & Yan et al. (2013a) \\
\hline Ps & P. scribneri & N/A & Potato & ND, U.S.A. & G. Yan & Yan et al. (2016a) \\
\hline Ps-c & P. scribneri & N/A & Corn & U.S.A. & A. Skantar & Yan et al. (2016a) \\
\hline $\mathrm{Pt}$ & P. thornei & N/A & Wheat & OR, U.S.A. & R. Smiley & Yan et al. (2013a, b) \\
\hline $\mathrm{Pa}$ & P. agilis & N/A & Corn & MD, U.S.A. & A. Skantar & Yan et al. (2013a) \\
\hline MB-3 & P. allius & N/A & Soybean & ND, U.S.A. & G. Yan & Yan et al. (2016c) \\
\hline $\mathrm{Hg} 13$ & Hoplolaimus sp. & N/A & Soybean & ND, U.S.A. & G. Yan & Yan et al. (2016c) \\
\hline Mn36 & Mesocriconema sp. & N/A & Soybean & ND, U.S.A. & G. Yan & Yan et al. (2016c) \\
\hline $\mathrm{Ha}$ & H. avenae & N/A & Wheat & U.S.A. & R. Smiley & Yan et al. (2013a, b) \\
\hline $\mathrm{Hs}$ & H. schachtii & N/A & Sugar beet & ND, U.S.A. & B. Nelson & Nelson et al. (2012) \\
\hline $\mathrm{Hg}$ & H. glycine & N/A & Soybean & U.S.A. & G. Yan & Author's collection \\
\hline $\mathrm{Hc}$ & H. ciceri & N/A & Chickpea & Syria & F. Toumi & Yan et al. (2013a) \\
\hline Hsm & Helicotylenchus sp. & N/A & Sugarbeet & MN, U.S.A. & G. Yan & Author's collection \\
\hline Pfp & Paratylenchus sp. & N/A & Field pea & MN, U.S.A. & G. Yan & Author's collection \\
\hline Hsm & Hoplolaimus sp. & N/A & Soybean & MN, U.S.A. & G. Yan & Author's collection \\
\hline Xsm & Xiphinema sp. & N/A & Soybean & MN, U.S.A. & G. Yan & Author's collection \\
\hline Tsm & Tylenchorhynchus sp. & N/A & Soybean & MN, U.S.A. & G. Yan & Author's collection \\
\hline $\mathrm{Cw}$ & Cactodera weissi & N/A & Potato & U.S.A. & A. Skantar & N/A \\
\hline $\mathrm{Ge}$ & Globodera ellingtonae & N/A & Potato & U.S.A. & A. Skantar & N/A \\
\hline $\mathrm{Gp}$ & G. pallida & N/A & Potato & IN, U.S.A. & A. Skantar & Skantar et al. (2007) \\
\hline Gr56 & G. rostochiensis & N/A & Potato & Canada & A. Skantar & N/A \\
\hline Gr38 & G. rostochiensis & N/A & Potato & NY, U.S.A. & A. Skantar & Skantar et al. (2007) \\
\hline Gt & G. tabacum tabacum & N/A & Tobacco & U.S.A. & A. Skantar & Skantar et al. (2007) \\
\hline Gtc & G. tabacum tabacum & N/A & Tobacco & U.S.A. & A. Skantar & Skantar et al. (2007) \\
\hline Mn & Meloidogyne naasi & N/A & Poa/bent & U.S.A. & A. Skantar & N/A \\
\hline $\mathrm{NC}$ & Nematode community & N/A & Potato & MN, U.S.A. & G. Yan & Author's collection \\
\hline $\mathrm{SDE}^{\mathrm{b}}$ & Soil DNA extract & N/A & Potato & MN, U.S.A. & G. Yan & Author's collection \\
\hline
\end{tabular}

\footnotetext{
a Not available.

${ }^{\mathrm{b}}$ Soil DNA extract from potato fields.
} 
Statistical analysis. The PROC REG in SAS (version 9.4, Statistical Analysis System; SAS Institute, Cary, NC) was used to establish the correlation relationship $\left(R^{2}>0.5, P<0.05\right)$ between nematode numbers based on the qPCR assay and traditional microscopic methods. The number of $P$. penetrans estimated by $\mathrm{qPCR}$ was regressed against the number of $P$. penetrans artificially added to autoclaved soil or quantified by the conventional methods. Comparison between $P$. penetrans estimates from the qPCR assay and microscopic methods was conducted by paired $t$ test (PROC TTEST) $(P<0.05)$ where an acceptance of the null hypothesis $(P>0.05)$ indicates no significant difference between nematode counts obtained from the two procedures.

\section{Results}

DNA extraction from soil. Nematode DNA was extracted directly from soil using the PowerSoil DNA Isolation Kit (MoBio). To examine the presence of inhibitors that might interfere with fluorescence generated in the qPCR reaction, amplification of $P$. penetrans DNA serially diluted with water was compared with that of DNA diluted with extracts of sterilized and noninfested Dechane-1 sandy-loam soil. The amplification efficiency value for DNA in soil extracts was 103 whereas that of DNA in water was 104, indicating that the PowerSoil DNA Isolation Kit was able to remove inhibitors from extracts of sterilized and noninfested soil.

Primer specificity and sensitivity. The primer pair Dechene-PpF/R was designed based on the D2-D3 expansion region of the $28 \mathrm{~S}$ rRNA sequence of $P$. penetrans. It produced the expected target amplicon of $111 \mathrm{bp}$ only for $P$. penetrans but not from the other 23 plantparasitic nematode spp. (31 isolates) used as control (Table 2). The $\mathrm{Cq}$ values of different numbers of $P$. penetrans isolates ranging from 23.42 to 27.23 produced a single melting peak at $85^{\circ} \mathrm{C}$ from the qPCR, indicating the presence of a single amplicon (Fig. 1).

Detection sensitivity of the assay was performed using a fine textured sandy-loam De Chene soil. The average $\mathrm{Cq}$ values obtained for the different numbers $(0.5,1,2,3$, and 5$)$ of $P$. penetrans added to $0.5 \mathrm{~g}$ of autoclaved soil were $31.83 \pm 0.4,30.84 \pm 0.2,30.39 \pm$ $1.0,29.04 \pm 0.65$, and $28.02 \pm 0.7$, respectively, suggesting that lower proportions of the nematode could have been detected.

Generation of a standard curve from soil. The standard curve was generated from the artificially infested soils at different densities $(0.5,1,5,25,125$, and 625 P penetrans per $0.25 \mathrm{~g}$ of soil). The equation obtained by plotting the $\mathrm{Cq}$ values versus the log of the starting materials was described as $y=-3.508 x+30.731$ (Fig. 2). The amplification efficiency $(\mathrm{E})$ was $92.8 \%$ and the $\mathrm{Cq}$ values ranged from 32.88 to 21.52 , and the relationship between the $\mathrm{Cq}$ values and the density of $P$. penetrans showed highly significant linearity $\left(R^{2}=\right.$ $0.983, P<0.001)$. No amplification was observed with control soils that were not infested with $P$. penetrans.

Validation of the standard curve. The equation of the above standard curve was used to estimate known numbers of $P$. penetrans in soil. Based on their $\mathrm{Cq}$ values, the average qPCR estimates for the infestation rates $(1,5,10,20,40$, or 80 per $0.25 \mathrm{~g}$ of soil) were 1.77 , $11.09,18.93,43.96,80.62$, and 216.85 per $0.25 \mathrm{~g}$ of soil, respectively. Thus, the correlation between the numbers of $P$. penetrans added to soil and the numbers determined by qPCR was highly significant $\left(R^{2}=0.91, P<0.001, n=36\right)$, described by the equation $y=$ $2.69 \mathrm{x}-7.6$ (Fig. 3).

Effect of grinding field soil on detection efficiency. The impact of grinding field soil on qPCR detection and quantification of $P$. penetrans was investigated by comparing qPCR detections between ground and unground field soils. The results showed that $80 \%$ of the total number of ground samples were detected whereas only $47 \%$ of the unground soil samples were positive. The detection efficiency was density dependent and significantly higher $(P<0.05)$ in ground soil than unground soil (Fig. 4). At 50 P. penetrans per $200 \mathrm{~g}$ of soil, only one of the three replications of the ground soil samples was detected whereas none was detected for the unground soil. At $100 P$. penetrans per $200 \mathrm{~g}$ of soil, two replications of the ground soil were detected whereas only one of the unground samples was detected. Although there was a difference in $\mathrm{Cq}$ values between ground and unground samples at certain densities, the gap was close at higher densities > 196 nematodes per $200 \mathrm{~g}$ soil. At 196 P. penetrans per $200 \mathrm{~g}$ of soil, all the ground treatments were detected whereas only two of the unground treatments were detected. At $210 P$. penetrans per $200 \mathrm{~g}$ of soil, all the replicates of both the ground and unground treatments were detected. Grinding of soil before DNA extraction was not necessary at population densities above 196 nematodes per $200 \mathrm{~g}$ of soil. The average $\mathrm{Cq}$ value obtained for all the ground treatments was 31.85 , not significantly different from that of the unground treatments, $31.19(P=0.82$, paired $t$ test) (Table 3$)$, indicating that grinding field soil may not have adverse effect on quantification accuracy.

Quantification of $\boldsymbol{P}$. penetrans from field soil. Correlation analysis was conducted to determine the relationship between nematode numbers detected by the qPCR assay and the numbers determined by the two traditional microscopic methods for the 20 soil samples collected from infested potato fields in MN (Table 4). There was a strong and significant positive correlation $\left(R^{2}=0.82 ; P<0.001\right)$ between the numbers of $P$. penetrans quantified based on the qPCR assay and sugar centrifugal extraction method described by the equation $y=8.66 x-393$ (Fig. 5). Whitehead tray method showed a relatively weaker but significant positive correlation $\left(R^{2}=0.61 ; P<0.001\right)$ described by the equation $\mathrm{y}=12.23 \mathrm{x}-411$ (Fig. 6). Similarly, there was significant positive correlation $\left(\mathrm{y}=0.5305 \mathrm{x}+22.731 ; R^{2}=\right.$ $0.75 ; P<0.001)$ between the sugar centrifugal extraction and quantification method, and the Whitehead tray method of extraction and quantification shown in Figure 7.

\section{Discussion}

An efficient and reliable diagnostic assay to quantify the presence of plant-parasitic nematodes in soil is critical for making management decisions. In this study, we report on the development of a qPCR assay for $P$. penetrans based on the D2-D3 expansion domain of the $28 \mathrm{~S}$ rDNA gene. $P$. penetrans was quantified directly in DNA extracts from field soils using a species-specific SYBR Green I-based qPCR. The qPCR assay was evaluated based on primer specificity, sensitivity, efficiency, and the relationship between $P$. penetrans numbers estimated from field soils by conventional methods and the qPCR assay. The assay was highly specific and able to differentiate P. penetrans from other Pratylenchus spp. and non-Pratylenchus plant-parasitic nematodes commonly found in potato fields in $\mathrm{MN}$. The qPCR assay was sensitive and detected genomic DNA of a single juvenile added to $1 \mathrm{~g}$ of sterilized soil. Artificially and naturally infested field soils with different $P$. penetrans population densities were used to validate the assay based on a standard curve generated by the assay. We also coupled mechanical grinding of field soil to qPCR amplification to improve $P$. penetrans detection efficiency in field soil.

The $P$. penetrans-specific primer set (Dechene-Pp-F/R) designed from the D2-D3 expansion region of the 28S rRNA showed high

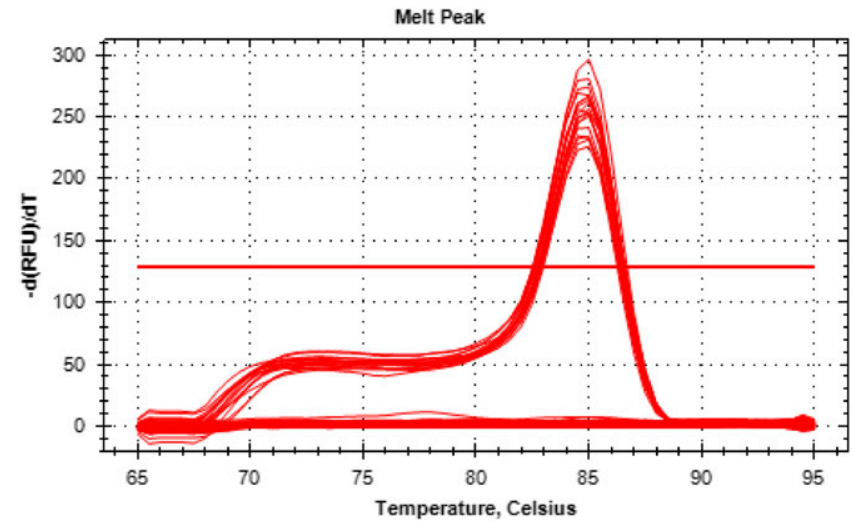

Fig. 1. Melting curve profiles of Pratylenchus penetrans-specific amplicons with melting temperature at $85^{\circ} \mathrm{C}$. Control reactions without $P$. penetrans DNA template did not produce any amplification. 
specificity to $P$. penetrans and consistently produced a single amplicon in melt curve analysis without specific amplification when DNA from nontarget nematodes were used. Only few $P$. penetrans-specific primers have been reported (Al-Banna et al. 2004; Mokrini et al. 2013; Mekete et al. 2011; Sato et al. 2007, Setterquist et al. 1996; Uehara et al. 1998; Waeyenberge et al. 2009). The new P. penetrans primers designed from the D2-D3 was also shown to be specific to our local $P$. penetrans populations. Previous studies (Al-Banna et al. 2004; Carta et al. 2001; Duncan et al. 1999; Waeyenberge et al. 2009) demonstrated that this region is stable in length within the genus Pratylenchus. On the contrary, other studies (Orui 1996; Uehara et al. 1998; Waeyenberge et al. 2000) have indicated that ITS sequences can vary in size between different Pratylenchus species but may show extensive polymorphism within a species or an individual, limiting its suitability for designing specific primers for a species with much sequence variation among different populations. Further testing of these primers with other Pratylenchus spp. and local species not included in this study may be recommended.

The sensitivity of the assay was evaluated by its ability to detect a minimum number of $P$. penetrans in $0.5 \mathrm{~g}$ of autoclaved soil. The assay could detect 0.5 juvenile in $0.5 \mathrm{~g}$ of soil, equivalent to 200 juveniles per $200 \mathrm{~g}$ of soil. The average $\mathrm{Cq}$ value for 0.5 juvenile per $0.5 \mathrm{~g}$ of soil was 31.83 , suggesting that our assay had the capacity to detect lower proportions of the nematode in $0.5 \mathrm{~g}$ of soil. This level of sensitivity is comparable with previous reports: detection sensitivity of $1 P$. thornei per $\mathrm{g}$ of soil and $1 P$. neglectus per $\mathrm{g}$ of soil was reported (Yan et al. 2012, 2013b). Sato et al. (2007) detected a single second-stage juvenile of $P$. penetrans mixed with 800 free-living nematodes whereas Toyota et al. (2008) reported a qPCR assay that detected a single second-stage juvenile of $G$. rostochiensis in 1,000 free-living nematodes. The economic threshold for $P$. penetrans is variable, and is contingent on the crop type, geographic location, environmental factors, edaphic factors, crop value, potential for disease complexes, nematode extraction procedures, etc. (Castillo and Vovlas 2007); however, with the presence of Verticillium dahliae (2 to 13 $\mathrm{cfu} / \mathrm{cm}^{3}$ ), the economic threshold for $P$. penetrans could be as low as 10 to 20 vermiforms per $100 \mathrm{~cm}^{3}$ of soil (Powelson 1993). We could detect as low as 23 P. penetrans per $200 \mathrm{~g}$ of soil, suggesting that the assay could be useful in establishing economic threshold limits for $P$. penetrans in potato fields.

The standard curve was generated from a range of nematode individuals added to soils and was used to quantify known numbers of

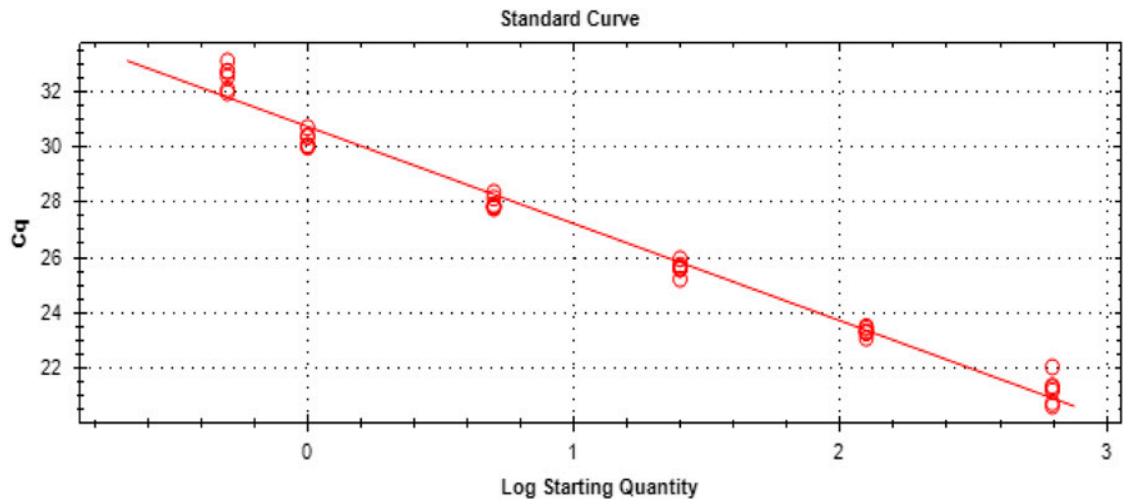

Fig. 2. Standard curve of the qPCR assay for Pratylenchus penetrans: quantification cycle number (Cq) plotted against the log of the number of $P$. penetrans $(0.5,1,5,25,125$, and 625 ) added to $0.25 \mathrm{~g}$ of sterilized soil. The DNA was extracted in duplicates and the qPCR were run in triplicate.

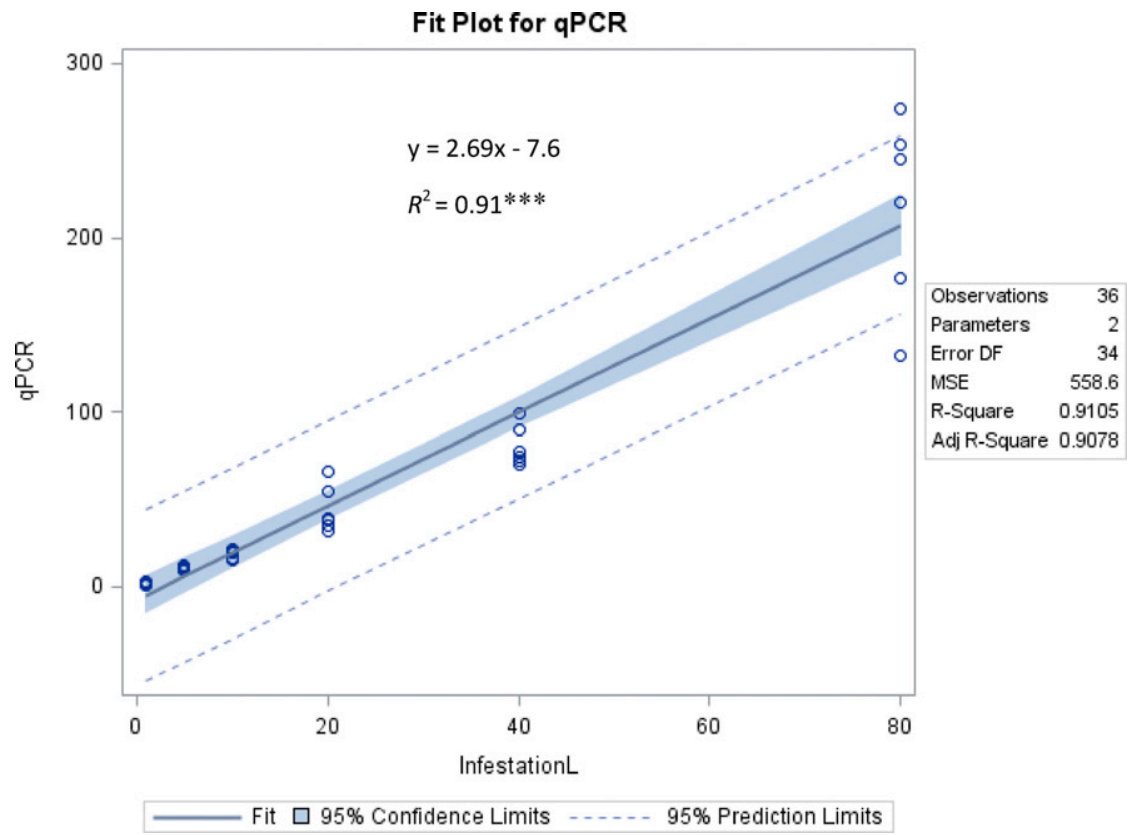

Fig. 3. Correlation between the number of Pratylenchus penetrans determined by quantitative PCR (qPCR) and the number of $P$. penetrans $(1,5,10,20,40$, and 80$)$ added to $0.25 \mathrm{~g}$ of sterilized and uninfested soil. DNA was extracted in duplicate and the qPCR were run in triplicate. ${ }^{* \star *}$ indicates significant at $P<0.0001$. 
nematodes in artificially infested soil. Not only were the Cq values of the standard curve significantly inversely correlated with the log values of nematode numbers $\left(R^{2}=0.98, P<0.001\right)$, but also the correlation between the numbers of $P$. penetrans added to soil and the numbers determined by $\mathrm{qPCR}$ was highly significant $\left(R^{2}=0.91\right.$, $P<0.0001$ ), showing the accuracy of the qPCR assay in estimating the numbers of $P$. penetrans in artificially infested soil samples. Sato et al. (2007) intimated that the accuracy of using standard curve to identify nematodes in a nematode community would be higher when

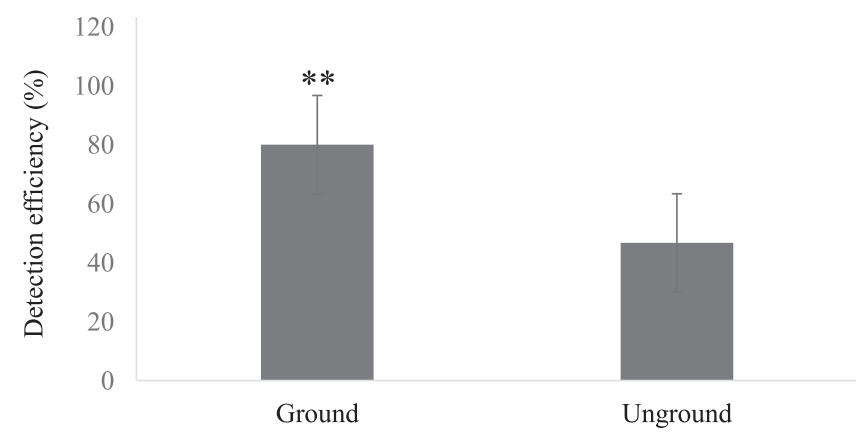

Fig. 4. Comparison of quantitative PCR (qPCR) detection efficiencies of Pratylenchus penetrans between ground and unground soils. Detection efficiency was determined by the percentage of the total number of observations detectable by the assay. ${ }^{* *}$ indicates significant $t$ test $(P<0.05)$. generated from individual nematodes than using serial dilutions from a concentrated DNA due to higher variations in DNA samples obtained from different numbers of nematode individuals than in simply diluted DNA samples. Moreover, it was demonstrated that standard curves generated from different nematode numbers, rather than serial dilution, tend to be more representative of the variation that may exist in natural field samples (Berry et al. 2008; Yan et al. 2012).

It is worthwhile to note that variation exists between the two methods of estimating $P$. penetrans. The variation between the qPCR estimates and the numbers of $P$. penetrans actually added to the soil was lower at lower densities $(1,5,10$ nematodes per $0.25 \mathrm{~g}$ soil) and highest at 80 nematodes per $0.25 \mathrm{~g}$ soil. Variations at this high population density are likely due to reduction in DNA extraction efficiency and the variation in the nematode DNA at different developmental stages. Sato et al. (2007) found that the Ct values of a male $P$. penetrans $(22.0 \pm 0.7)$ and a female $(23.0 \pm 0.3)$ with larger body sizes were significantly lower $(P<0.05)$ than those from small juveniles $(25.1 \pm 0.4)$. However, under field conditions, densities $<8,000$ nematodes per $200 \mathrm{~g}$ soil may be more realistic than 64,000 nematodes per $200 \mathrm{~g}$ soil, which further suggests that the assay can reliably be used to estimate $P$. penetrans numbers under normal field conditions.

In our previous study, a combination of soil grinding and conventional PCR was developed to sensitively detect soybean cyst nematode Heterodera glycines (Baidoo et al. 2017). The present study demonstrates that this method is applicable to the root-lesion nematode $P$. penetrans. The effect of grinding was parallel to compaction

Table 3. Effect of grinding field soil on Pratylenchus penetrans detection and quantification efficiency ${ }^{\mathrm{a}}$

\begin{tabular}{|c|c|c|c|c|c|c|}
\hline Sample ID & Replication & Nematodes/200 g soil & Detected/not detected & Detection efficiency $(\%)$ & $\mathbf{C q}$ & Mean Cq \\
\hline \multirow[t]{3}{*}{5 nematodes ground } & Rep 1 & 50 & n.d. & & N/A & \\
\hline & Rep 2 & 50 & + & 33.3 & 31.99 & 31.99 \\
\hline & Rep 3 & 50 & n.d. & & N/A & \\
\hline \multirow[t]{3}{*}{5 nematodes unground } & Rep 1 & 50 & n.d. & & N/A & n.d. \\
\hline & Rep 2 & 50 & n.d. & 0 & N/A & \\
\hline & Rep 3 & 50 & n.d. & & N/A & \\
\hline \multirow[t]{3}{*}{10 nematodes ground } & Rep 1 & 100 & n.d. & & N/A & \\
\hline & Rep 2 & 100 & + & 66.6 & 34.9 & 34.6 \\
\hline & Rep 3 & 100 & + & & 33.62 & \\
\hline \multirow[t]{3}{*}{10 nematodes unground } & Rep 1 & 100 & n.d. & & N/A & \\
\hline & Rep 2 & 100 & n.d. & 33.3 & N/A & 31.73 \\
\hline & Rep 3 & 100 & + & & 31.73 & \\
\hline \multirow[t]{3}{*}{ Y2-P25 ground } & Rep1 & 23 & + & & 34.76 & \\
\hline & Rep 2 & 23 & + & 100 & 34.94 & 33.82 \\
\hline & Rep 3 & 23 & + & & 31.78 & \\
\hline \multirow[t]{3}{*}{ Y2-P25 unground } & Rep 1 & 23 & + & & 34.24 & \\
\hline & Rep 2 & 23 & n.d. & 33.3 & N/A & 34.24 \\
\hline & Rep 3 & 23 & n.d. & & N/A & \\
\hline \multirow[t]{3}{*}{ Y2p.1 ground } & Rep 1 & 210 & + & & 31.69 & \\
\hline & Rep 2 & 210 & + & 100 & 32.72 & 31.81 \\
\hline & Rep 3 & 210 & + & & 31.04 & \\
\hline \multirow[t]{3}{*}{ Y2p.1 unground } & Rep 1 & 210 & + & & 30.28 & \\
\hline & Rep 2 & 210 & + & 100 & 33.46 & 31.72 \\
\hline & Rep 3 & 210 & + & & 31.43 & \\
\hline \multirow{3}{*}{ P25 ground } & Rep 1 & 196 & + & & 28.71 & \\
\hline & Rep 2 & 196 & + & 100 & 28.00 & 28.26 \\
\hline & Rep 3 & 196 & + & & 28.08 & \\
\hline \multirow[t]{3}{*}{ P25 unground } & Rep 1 & 196 & n.d. & & N/A & \\
\hline & Rep 2 & 196 & + & 66.6 & 28.55 & 28.56 \\
\hline & Rep 3 & 196 & + & & 28.64 & \\
\hline \multirow[t]{3}{*}{ De Chene 1 ground } & Rep 1 & 0 & n.d. & - & N/A & \\
\hline & Rep 2 & 0 & n.d. & - & N/A & n.d. \\
\hline & Rep 3 & 0 & n.d. & - & N/A & \\
\hline \multirow{3}{*}{ De Chene 1 unground } & Rep 1 & 0 & n.d. & - & N/A & \\
\hline & Rep 2 & 0 & n.d. & - & N/A & n.d. \\
\hline & Rep 3 & 0 & n.d. & - & N/A & \\
\hline
\end{tabular}

\footnotetext{
${ }^{\mathrm{a}}$ n.d = not detected; N/A = not applicable; $+=$ detected.
} 
reported by Goto et al. (2009). We determined that grinding of the field soil before DNA extraction could increase $P$. penetrans detection efficiency from 47 to $80 \%$. We found that grinding did not significantly affect the amount of DNA recovered from the soil at higher population densities ( $\geq 196$ nematodes per $200 \mathrm{~g}$ of soil) evident in similarity in $\mathrm{Cq}$ values between the ground and the unground samples. On the contrary, there was a difference in $\mathrm{Cq}$ between ground (34.6) and unground (31.73) at 100 nematodes per $200 \mathrm{~g}$ soil. The most reasonable explanation to this is that, in the unground sample, the nematodes are picked intact in the $0.25 \mathrm{~g}$ sample used for DNA extraction and the amount of DNA recovered depends on the number

Table 4. Comparison of Pratylenchus penetrans estimations by different methods in $200 \mathrm{~g}$ of soil

\begin{tabular}{lccr}
\hline $\begin{array}{l}\text { Field } \\
\text { sample ID }\end{array}$ & $\begin{array}{c}\text { Sugar } \\
\text { centrifugation } \\
\text { method }\end{array}$ & $\begin{array}{c}\text { Whitehead } \\
\text { tray } \\
\text { method }\end{array}$ & $\begin{array}{r}\text { qPCR } \\
\text { assay }\end{array}$ \\
\hline P25-Nat-Rep 10 & 663 & 354 & 3,068 \\
P25-Rep 3 & 224 & 98 & 925 \\
P90 & 213 & 126 & 937 \\
P25 & 260 & 231 & 878 \\
P15 & 120 & 176 & 697 \\
P51 & 143 & 80 & 592 \\
P86 & 126 & 120 & 547 \\
P59 & 201 & 56 & 463 \\
P89 & 64 & 173 & 289 \\
H-11 & 42 & 25 & 284 \\
Y2P1 & 133 & 115 & 234 \\
P54 & 140 & 125 & 188 \\
P.13 & 75 & 40 & 127 \\
Hayes plant & 12 & 22 & 86 \\
centre & & & \\
P14 & 42 & 18 & 77 \\
Cambel East 1 & 13 & 0 & 0 \\
P18 & 13 & 0 & 0 \\
Y2P3 east & 0 & 40 & 0 \\
Dechane 1 & 0 & 0 & 0 \\
Y2P16 & 0 & 0 & 0 \\
\hline
\end{tabular}

of intact nematodes per $0.25 \mathrm{~g}$ of soil. Thus, at lower densities, the probability of picking an intact nematode is low, resulting in low detection efficiency, but once detected, the $\mathrm{Cq}$ value is expected to be equivalent to that of at least 1 nematode per $0.25 \mathrm{~g}$ soil. This suggests that at lower densities ( $\leq 100$ nematodes per $200 \mathrm{~g}$ soil), not grinding the field soil before DNA extraction may not only lead to lower detection efficiency (false negative results), but also could lead to overestimation of $P$. penetrans population densities. However, at lower density ( $\leq 100$ nematodes per $200 \mathrm{~g}$ soil), the $\mathrm{Cq}$ value may be high but the possibility of false negative is reduced. Thus, grinding the soil helps break the nematode body and homogenizes its content in the sample, which appears to be critical for detection. Mixing is important because of the patchy spatial distribution of nematodes in soil plus only a small amount of soil is used for detection. In agreement with our observation, Tsai and Olson (1992) used a rapid freeze-andthaw method to detect less than three Escherichia coli cells per $\mathrm{g}$ of infested soils, similar to that of Volossiouk et al. (1995), who reported that disruption of Verticillium dahliae by grinding in liquid nitrogen with natural abrasives enabled its direct detection from the soil. Nevertheless, grinding field soil can be difficult for heavy and moist soils, but air drying the field soil for at least $8 \mathrm{~h}$ facilitates grinding.

The qPCR assay was used to quantify $P$. penetrans in 20 field soil samples. There was a strong, significant positive correlation between the $P$. penetrans numbers estimated by conventional nematode extraction and quantification methods (centrifugal sugar flotation method and Whitehead tray method) and the qPCR method, suggesting that the assay can be used to estimate $P$. penetrans population density in field soils. However, the strength of the correlation was lower in field soil samples $\left(R^{2}=0.82\right.$ or $\left.R^{2}=0.61 ; P<0.001\right)$ compared with the artificially infested soil $\left(R^{2}=0.91 ; P<0.001\right)$. Such discrepancies may be attributed to the lack of uniformity in nematode distribution within a given soil sample: giving the same extraction method, different laboratories produced different numbers of $P$. neglectus using the same sample reflecting the difficulty in Pratylenchus sp. quantification using traditional microscopic methods (Yan et al. 2013b). In spite of these variations, the correlations obtained in this study between the two methods and the qPCR was comparable to previous reports (Ophel-Keller et al. 2008; Yan et al. 2012, 2013b).

This developed qPCR assay tended to overestimate the numbers of nematodes in both artificially infested and the field soils in

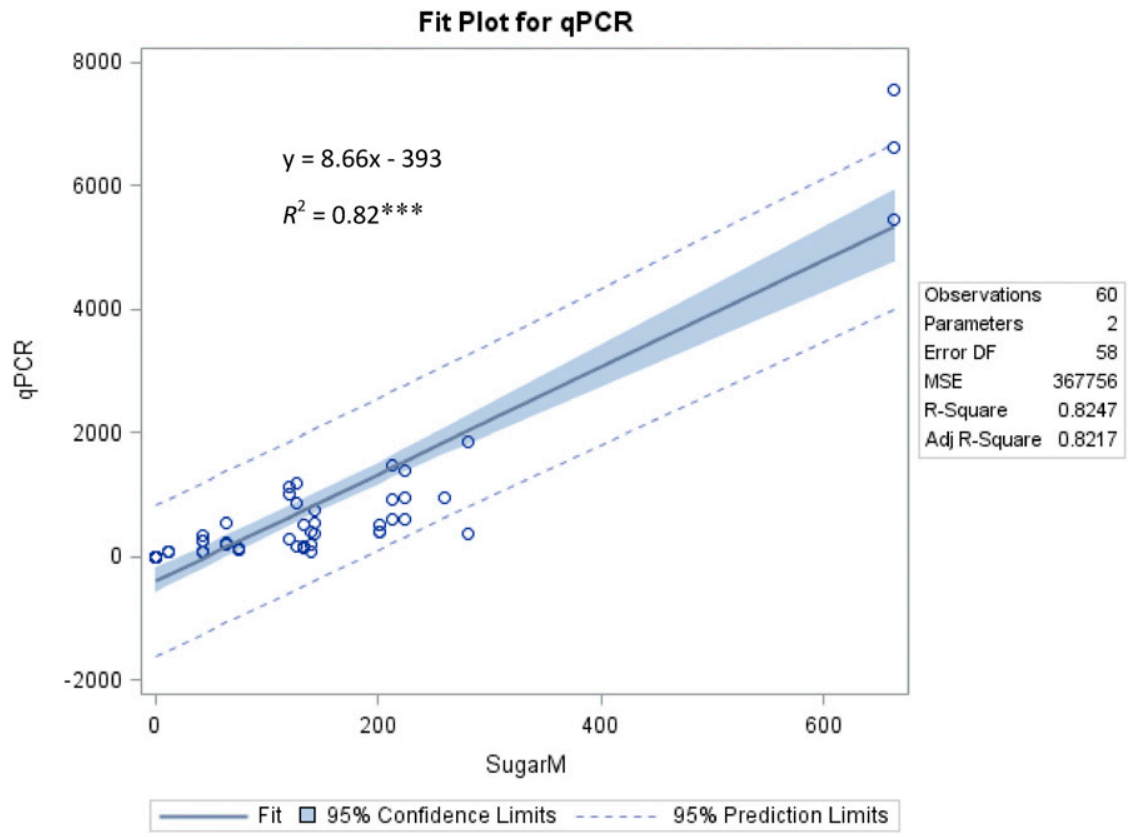

Fig. 5. Correlation between the numbers of Pratylenchus penetrans determined by the quantitative PCR (qPCR) and by the centrifugal sugar flotation extraction and microscopic counting method (SugarM) from 20 different field soil samples. ${ }^{* * *}$ indicates significant at $P<0.001$. DNA was extracted from each field sample in triplicate. 
comparison with the conventional methods similar to previous reports (Goto et al. 2009; Ophel-Keller et al. 2008; Toyota et al. 2008; Yan et al. 2012). These differences could be attributed to a number of factors. Firstly, conventional methods estimate the number of $P$. penetrans based on the number of adults and juveniles with visual diagnostic features without consideration of the eggs in the sample. Also, ergonomic errors associated with nematode extraction, sampling from nematode suspensions, and nematode counting may undermine the accuracy of the conventional estimates. Bellvert et al. (2008) observed that nematode extraction efficiency was dependent on the initial soil volume used, soil type, residual moisture in samples prior to extraction, and the extraction method with efficiencies ranging from 33 to $84 \%$, suggesting a high risk of underestimating numbers with the traditional detection methods. The patchy spatial and uneven distribution of nematodes in field soils may affect their quantification by different methods (Ophel-Keller et al. 2008; Waeyenberge et al. 2000; Whitehead and Hemming 1965). In comparison, a small amount of soil $(0.25 \mathrm{~g})$ was used for DNA extraction using the PowerSoil DNA Isolation Kit whereas approximately $200 \mathrm{~g}$ of soil was processed using the conventional methods. These discrepancies may help explain why sample Y2P1, with 210 nematodes estimated by the centrifugal sugar flotation method, produced a higher

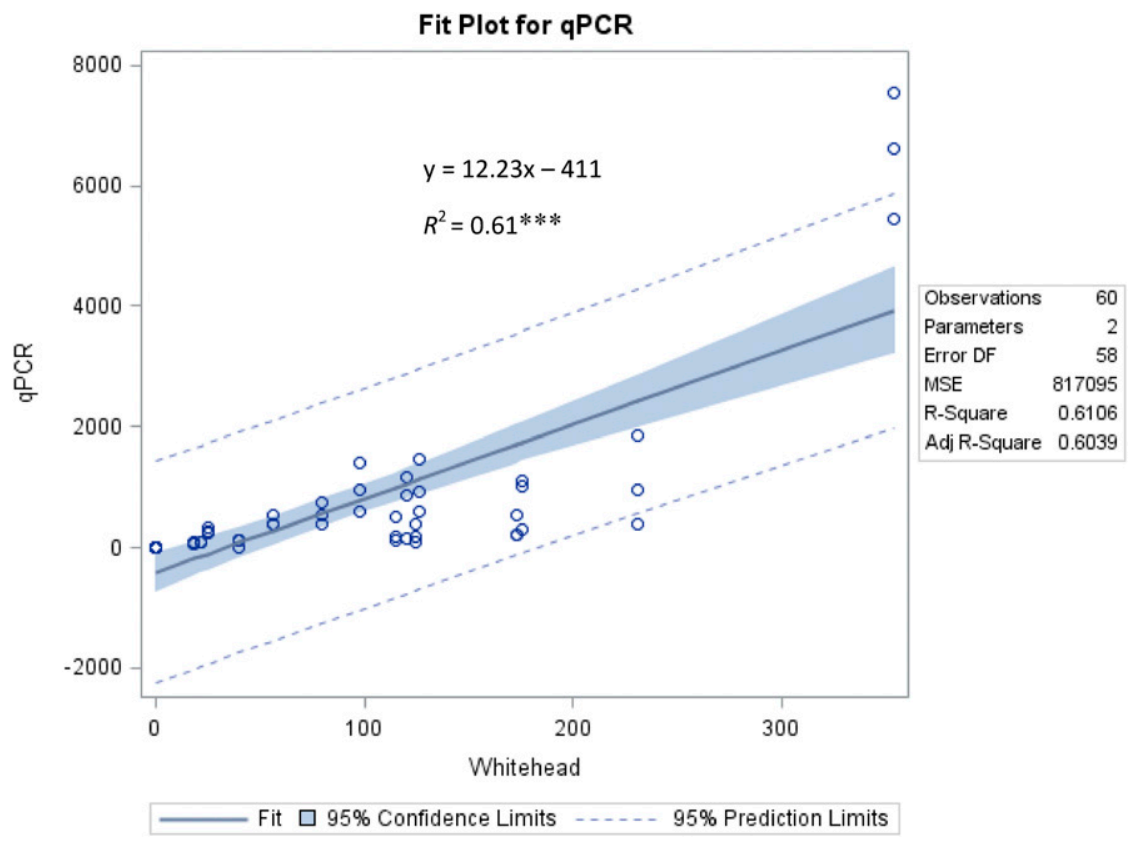

Fig. 6. Correlation between the numbers of Pratylenchus penetrans determined by the quantitative PCR (qPCR) and by the Whitehead tray extraction and microscopic counting method (Whitehead) from 20 different field soil samples. ${ }^{* \star *}$ indicates significant at $P<0.001$. DNA was extracted from each field sample in triplicate.

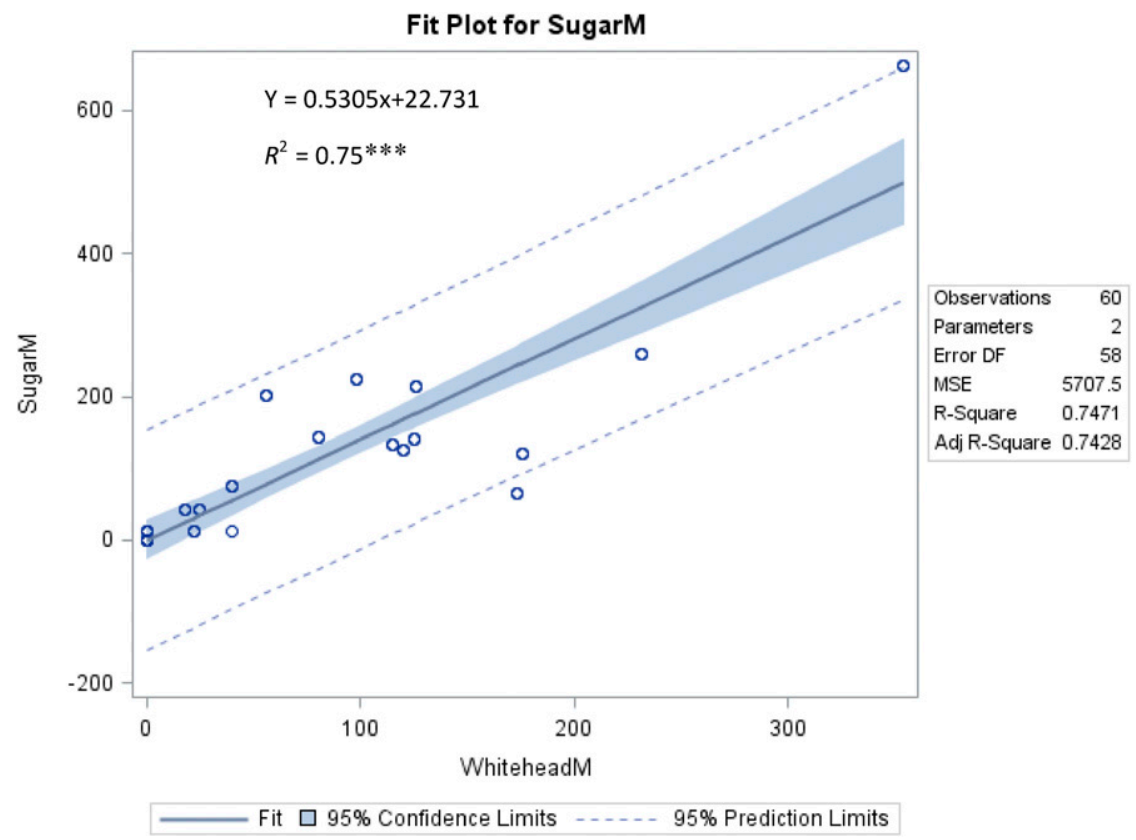

Fig. 7. Correlation between the numbers of Pratylenchus penetrans determined by the centrifugal sugar flotation extraction and microscopic counting method (SugarM), and by the Whitehead tray extraction and microscopic counting method (WhiteheadM) from 20 different field soil samples. ${ }^{* \star}$ indicates significant at $P<0.001$. DNA was extracted from each field sample in triplicate. 
Cq value of 31.8 (meaning a lower population density) than P25 (28.4) with 196 nematodes. Although the qPCR method seems to overestimate nematode numbers, it is important to note that the assay establishes equations relating qPCR numbers to the traditional quantification numbers, which means that the $\mathrm{qPCR}$ estimates can be used to obtain the traditional estimates mathematically.

Identification and quantification of plant-parasitic nematodes directly from soil DNA extract (Li et al. 2014; Sato et al. 2010; Yan et al. 2008, 2012, 2013b) is an extra step in technological advancement compared with quantification using individual nematodes from nematode suspension or communities (Berry et al. 2008, Koyama et al. 2016; Madani et al. 2005, Sato et al. 2007; Toyota et al. 2008). This paper presents another protocol using a SYBR Green I dye species-specific qPCR assay to detect and quantify $P$. penetrans directly from infested soils from potato fields. The qPCR assay will be useful for differentiating $P$. penetrans from mixed populations of either $P$. crenatus, $P$. neglectus, $P$. scribneri, or $P$. thornei on potato in North America. We coupled manual grinding of field soil to qPCR quantification for improved direct detection and quantification of $P$. penetrans from a large number of field soil samples. The assay obviates the time-consuming steps of conventional nematode extraction, microscopic identification, and counting, requires no expertise in nematode taxonomy and morphology, and can serve as a useful diagnostic tool not only in research, but also in diagnostic labs and extension services for pest management. Although the soil processing and DNA extraction methods presented in this study did not seem to affect PCR amplification efficiency for the different field soils used, it is important to note that this may not accurately reflect all other soil types and conditions. Our understanding of how different soil types and conditions affect direct DNA amplification from soil is limited and needs to be elucidated in future research.

\section{Acknowledgments}

This research was supported by the Northern Plains Potato Growers Association, Minnesota Area II Potato Research and Promotion Council, and USDA/ Minnesota Department of Agriculture. The authors express their sincere appreciation to Danqiong Huang for technical assistance, Addison Plaisance and Arjun Upadhaya for collecting soil samples, preparing carrot cultures, and assaying nematodes, and the Minnesota potato growers for availing their farm properties from which soil samples were taken.

\section{Literature Cited}

Al-Banna, L., Ploeg, A. T., Williamson, V. M., and Kaloshian, I. 2004. Discrimination of six Pratylenchus species using PCR and species-specific primers. J. Nematol. 36:142-146.

Baidoo, R., Yan, G. P., Nelson, B., Skantar, A. M., and Chen, S. 2017. Use of chemical flocculation and nested PCR for Heterodera glycines detection in DNA extracts from field soils with low population densities. Plant Dis. 101:1153-1161.

Bellvert, J., Crombie, K., and Horgan, F. G. 2008. Comparative efficiency of the Fenwick Can and Schuiling centrifuge in extracting nematode cysts from different soil types. J. Nematol. 40:30-34.

Berry, S. D., Fargette, M., Spaull, V. W., Morand, S., and Cadet, P. 2008. Detection and quantification of root-knot nematode (Meloidogyne javanica), lesion nematode (Pratylenchus zeae) and dagger nematode (Xiphinema elongatum) parasites of sugarcane using real-time PCR. Mol. Cell. Probes 22:168-176.

Brown, M. J., Riedel, R. M., and Rowe, R. C. 1980. Species of Pratylenchus associated with Solanum tuberosum cv Superior in Ohio. 1. Nematol. 12:189-192.

Carta, L. K., Skantar, A. M., and Handoo, Z. A. 2001. Molecular, morphological and thermal characters of 19 Pratylenchus spp. and relatives using the D3 segment of the nuclear LSU rRNA gene. Nematropica 31:193-207.

Castillo, P., and Vovlas, N. 2007. Pratylenchus (Nematoda: Pratylenchidae): Diagnosis, biology, pathogenicity and management. Nematology Monographs and Perspectives 6. Brill, Leiden, The Netherlands.

Coolen, W. A., and D'Herde, C. J. 1970. Nematodes associated with glasshouse roses. Pages 259-266 in: Proceedings of the International Nematology Symposium (Warsaw, 1967). Zeszyty Problemowe Postepow Nauk Rolniczych 92.

Duncan, L. W., Inserra, R. N., Thomas, W. K., Dunn, D., Mustika, I., Frisse, L. M., Mendes, M. L., Morris, K., and Kaplan, D. T. 1999. Molecular and morphological analysis of isolates of Pratylenchus coffeae and closely related species. Nematropica 29:61-80.

Francl, L. J., Madden, L. V., Rowe, R. C., and Riedel, R. M. 1987. Potato yield loss prediction and discrimination using preplant population densities of Verticillium dahliae and Pratylenchus penetrans. Phytopathology 77:579-584.

Goto, K., Sato, E., and Toyota, K. 2009. A novel detection method for the soybean cyst nematode Heterodera glycines using soil compaction and real-time PCR. Jpn. J. Nematol. 39:1-7.
Jenkins, W. R. 1964. A rapid centrifugal-flotation technique for separating nematodes from soil. Plant Dis. Rep. 48:692.

Kimpinski, J. 1979. Root lesion nematodes in potatoes. Am. Potato J. 56:79-86.

Koyama, Y., Toyota, K., Miyamaru, N., Yoshida, K., and Uesugi, K. 2016. Development of a quantitative method with real-time PCR for three Pratylenchus species causing damage to chrysanthemum in Japan. Nematology 18:687-695.

Li, Y., Lawrence, G. W., Lu, S., Balbalian, C., and Klink, V. P. 2014. Quantitative field testing Heterodera glycines from Metagenomic DNA samples isolated directly from soil und agronomic production. PLoS One 9:e89887.

Luc, M. 1987. A reappraisal of Tylenchina (Nemata). 7. The family Pratylenchidae Thorne, 1949. Rev. Nematol. 10:203-218.

MacGuidwin, A. E., and Rouse, D. I. 1990. Role of Pratylenchus penetrans in the potato early disease of Russet Burbank potato. Phytopathology 80:1077-1082.

Madani, M., Subbotin, S. A., and Moens, M. 2005. Quantitative detection of the potato cyst nematode, Globodera pallida and the beet cyst nematode, Heterodera schachtii, using real-time PCR with SYBR Green I dye. Mol Cell. Probes 19:81-86.

Martin, M. J., Riedel, R. M., and Rowe, R. C. 1982. Verticillium dahliae and Pratylenchus penetrans: Interaction in the early dying complex of potato in Ohio. Phytopathology 72:640-644.

Mekete, T., Gray, M., Niblack, T., Lopez-Nicora, H., and Reynolds, K. 2011 Distribution and diversity of root-lession nematode (Pratylenchus spp.) associated with Miscanthus $\times$ giganteus and Panicum virgatum used for biofuels, and species identification in a multiplex polymerase chain reaction. Nematology 13:673-686.

Mokrini, F., Waeyenberge, L., Viaene, N., Andaloussi, F. A., and Moens, M. 2013 Quantitative detetion of the root-lesion nematode, Pratylenchus penetrans, using qPCR. Eur. J. Plant Pathol. 137:403-413.

Mokrini, F., Waeyenberge, L., Viaene, N., and Moens, M. 2012. Occurrence of nematodes of the Heterodera avenae group and Pratylenchus spp. on wheat and barley in Morocco. (Abstr.) Proceedings of the 31st International Symposium of the European Society of Nematologists Adana, Turkey.

Nelson, B. D., Bolton, M. D., Lopez-Nicora, H. D., Niblack, T. L., and del Rio Mendoza, L. 2012. First confirmed report of sugar beet cyst nematode, Heterodera schachtii, in North Dakota. Plant Dis. 96:772.

Olthof, T. H. A., and Potter, J. W. 1973. The relationship between population densities of Pratylenchus penetrans and crop losses in summer-maturing vegetables in Ontario. Phytopathology 63:577-582.

Ophel-Keller, K., McKay, A., Hartley, D., Herdina, and Curran, J. 2008 Development of a routine DNA-based testing service for soilborne diseases in Australia. Australas. Plant Pathol. 37:243-253.

Orui, Y. 1996. Discrimination of the main Pratylenchus species in Japan by PCR RFLP analysis. Appl. Entomol. Zool. (Jpn.) 31:505-514.

Pinochet, J., Fernandez, C., and Sarah, J. L. 1995. Influence of temperature on in vitro reproduction of Pratylenchus coffeae, P. goodeyi and Radopholus similis. Fundam. Appl. Nematol. 18:391-392.

Powelson, M. L. 1993. Biology and management of early dying of potatoes. Annu. Rev. Phytopathol. 31:111-126.

Pudasaini, M. P., Viaene, N., and Moens, M. 2007. The influence of host and temperature on the vertical migration of Pratylenchus penetrans. Nematology 9:437-447.

Rowe, R. C., Davis, J. R., Powelson, M. L., and Rouse, D. I. 1987. Potato early dying: Causal agents and management strategies. Plant Dis. 71:482-489.

Rowe, R. C., Riedel, R. M., and Martin, M. J. 1985. Synergistic interactions between Verticillium dahliae and Pratylenchus penetrans in potato early dying disease. Phytopathology 75:412-18.

Sato, E., Goto, K., Min, Y. Y., Toyota, K., and Suzuki, C. 2010. Quantitative detection of Pratylenchus penetrans from soil using soil compaction and real-time PCR. Nematol. Res. 40:1-6.

Sato, E., Min, Y. Y., Shirakashi, T., Wada, S., and Toyota, K. 2007. Detection of the root-lesion nematode, Pratylenchus penetrans (Cobb), in a nematode community using real-time PCR. Jpn. J. Nematol. 37:87-92.

Sato, E., Suga, Y., Kisaki, C., Toyota, K., Miyake, K., Takada, A., Takeuchi, K., and Matsuura, R. 2011. Quantification of Pratylenchus penetrans in radish fields using a combination method of soil compaction and real-time PCR to determine the economic threshold. Soil Sci. Plant Nutr. 57:213-220.

Seinhorst, J. W. 1998. The common relation between population density and plant weight in pot and microplot experiments with various nematode plant combinations. Fundam. Appl. Nematol. 21:459-468.

Setterquist, R. A., Smith, G. K., Jones, R., and Fox, G. E. 1996. Diagnostic probes targeting the major sperm protein gene that may be useful in the molecular identification of nematodes. J. Nematol. 28:414-421.

Skantar, A. M., Handoo, Z. A., Carta, L. K., and Chitwood, D. J. 2007. Morphological and molecular identification of Globodera pallida associated with potato in Idaho. J. Nematol. 39:133-144.

Subbotin, S. A., Peng, D., and Moens, M. 2001. A rapid method for the identification of the soybean cyst nematode Heterodera glycines using duplex PCR. Nematology 3:365-371.

Subbotin, S. A., Ragsdale, E. J., Mullens, T., Roberts, P. A., Mundo-Ocampo, M., and Baldwin, J. G. 2008. A phylogenetic framework for root lesion nematodes of the genus Pratylenchus (Nematoda): evidence from 18S and D2-D3 expansion segments of $28 \mathrm{~S}$ ribosomal RNA genes and morphological characters. Mol. Phylogenet. Evol. 48:491-505. 
Talavera, M., Itou, K., and Mizukubo, T. 2001. Reduction of nematode damage by root colonization with arbuscular (Glomus spp.) in tomato Meloidogyne incognita (Tylenchida: Meloidogynidae) and carrot Pratylenchus penetrans pathosystems. Appl. Entomol. Zool. (Jpn.) 36:387-392.

Tarte, R., and Mai, W. F. 1976. Morphological variation in Pratylenchus penetrans. J. Nematol. 8:185-195.

Thies, J. A., Petersen, A. D., and Barnes, D. K. 1995. Host suitability of forage grasses and legumes for root-lesion nematode Pratylenchus penetrans. Crop Science 35:1647-1651.

Toyota, K., Shirakashi, T., Sato, E., and Wada, S. 2008. Development of a realtime PCR method for the potato-cyst nematode Globodera rostochiensis and the root-knot nematode Meloidogyne incognita. Soil Sci. Plant Nutr. 54:72-76.

Troccoli, A., Lamberti, F., and Greco, N. 1992. Pratylenchus species occurring in Algeria (Nematoda, Pratylenchidae). Nematol. Mediterr. 20:97-103.

Tsai, Y. L., and Olson, B. H. 1992. Detection of low numbers of bacterial cells in soils and sediments by polymerase chain reaction. Appl. Environ. Microbiol. 58:754-757.

Uehara, T., Mizukubo, T., Kushida, A., and Momota, Y. 1998. Identification of Pratylenchus penetrans (Cobb) by PCR using ITS-based specific. Jpn. J. Nematol. 28:1-7.

Volossiouk, T., Robb, E. J., and Nazar, N. R. 1995. Direct DNA extraction for PCRmediated assays of soil organisms. Appl. Environ. Microbiol. 61:3972-3976.

Waeyenberge, L., Moens, M., Pinochet, J., and Vrain, T. C. 2000. Molecular characterization of Pratylenchus species using rDNA restriction fragment length polymorphisms. Nematology 2:135-142.

Waeyenberge, L., Viaene, N., and Moens, M. 2009. Species-specific duplex PCR for the detection of Pratylenchus penetrans. Nematology 11:847-857.

Westerdahl, B. B., Giraud, D., Etter, S., Riddl, L. J., Radewald, J. D., Anderson, C. A., and Darso, J. 2003. Management options for Pratylenchus penetrans in Easter lily. J. Nematol. 35:443-449.

Wheeler, T. A., Madden, L. V., Rowe, R. C., and Riedel, R. M. 1992. Modeling of yield loss in potato early dying caused by Pratylenchus penetrans and Verticillium dahliae. J. Nematol. 24:99-102.

Whitehead, A. G., and Hemming, J. R. 1965. A comparison of some quantitative methods of extracting small vermiform nematodes from soil. Ann. Appl. Biol. 55:25-38.
Wishart, J., Philips, M. S., and Blok, V. C. 2002. Ribosomal intergenic spacer: a polymerase chain reaction diagnostic for Meloidogyne chitwoodi, M. fallax, and M. hapla. Phytopathology 92:884-892.

Yan, G. P., and Plaisance, A. 2016. Vermiform plant-parasitic nematodes on soybean in North Dakota and their relationship with soybean cyst nematodes. 459-P, American Phytopathological Society Annual Meeting, Tampa, FL, July 30-August 3.

Yan, G. P., Plaisance, A., Huang, D., Gudmestad, N. C., and Handoo, Z. A. 2016a First report of the root-lesion nematode Pratylenchus scribneri infecting potato in North Dakota. Plant Dis. 100:1023.

Yan, G. P., Plaisance, A., Huang, D., Liu, Z., Chapara, V., and Handoo, Z. A. 2016b. First report of the root-lesion nematode Pratylenchus neglectus on wheat (Triticum aestivum) in North Dakota. Plant Dis. 100:1794.

Yan, G. P., Plaisance, A., Huang, D., Upadhaya, A., Gudmestad, N. C., and Handoo, Z. A. 2016c. First report of the stubby root nematode Paratrichodorus allius on potato in North Dakota. Plant Dis. 100:1247.

Yan, G. P., Smiley, R. W., and Okubara, P. A. 2012. Detection and quantification of Pratylenchus thornei in DNA extracted from soil using real-time PCR. Phytopathology 102:14-22.

Yan, G. P., Smiley, R. W., Okubara, P. A., Skantar, A., Easley, S. A., Sheedy, J. G., and Thompson, A. L. 2008. Detection and discrimination of Pratylenchus neglectus and $P$. thornei in DNA extracts from soil. Plant Dis. 92:1480-1487.

Yan, G. P., Smiley, R. W., Okubara, P. A., and Skantar, A. M. 2013a. Speciesspecific PCR assay for differentiating Heterodera filipjevi and $H$. avenae. Plant Dis. 97:1611-1619.

Yan, G. P., Smiley, R. W., Okubara, P. A., Skantar, A. M., and Reardon, C. L. 2013b. Developing a real-time PCR assay for detection and quantification of Pratylenchus neglectus in soil. Plant Dis. 97:757-764.

Ye, W. 2012. Development of prime time-real-time PCR for species identification of soybean cyst nematode (Heterodera glycines Ichinohe, 1952) in North Carolina. J. Nematol. 44:284-290.

Zijlstra, C., Donkers-Venne, D. T. H. M., and Fargette, M. 2000. Identification of Meloidogyne incognita, $M$. javanica and $M$. arenaria using sequence characterized amplified region (SCAR) based PCR assays. Nematology 2: 847-853 